\author{
Дідух C.M. \\ кандидат економічних наук \\ кафедра економіки промисловості \\ Одеська національна академія харчових технологій \\ вул. Канатна, 112, м. Одеса, Україна, 65039 \\ E-mail: didukhsm@i.ua
}

\title{
ОЦІНКА ФІНАНСОВОГО СТАНУ ТА ДИНАМІКИ РОЗВИТКУ АГРОХОЛДИНГІВ УКРАЇНИ
}

Основною метою статті є дослідження особливостей розвитку, фрінансового стану та структури капіталу провідних агрохолдингів країни в умовах несприятливого макроекономічного середовища. Проведено аналіз особливостей розвитку агрохолдингів України на прикладі Kernel Holding S.A. і MHP S.A. Досліджено структуру їх доходів, динаміку фінансових показників та структуру капіталу. Проведено експрес-дослідження фрінансової стійкості даних компаній за системою показників У. Бівера.

Ключові слова: агрохолдинг, Kernel Holding S.A., MHP S.A., фрінансовий стан, структура капіталу, система показників У. Бівера.

Постановка проблеми та її зв'язок із важливими науковими та практичними завданнями. У розвитку економіки України дедалі більшу роль відіграють агрохолдинги, які проводять політику концентрації земельних угідь та формують потужні вертикально інтегровані структури. Їх кількість зростає - у 2007 році в Україні було зареєстровано 18 агрохолдингів, що мали у користуванні 1,7 млн. га. земельних угідь, а на початок 2013 року в країні нараховувалось вже майже 80 агрохолдингів, які обробляли більше ніж 10 млн. га [1]. За оцінками експертів в управлінні агрохолдингів знаходиться 27,9 \% площ сільськогосподарських угідь країни, що перебувають у використанні сільськогосподарських підприємств [2].

Вертикально інтегровані агрохолдинги відіграють важливу роль у впровадженні інноваційних технологічних рішень, підвищенні врожайності, нарощуванні експорту сільськогосподарської продукції та продуктів харчування. В період інтенсивного розвитку вони використовували переважно позиковий капітал для придбання чи будівництва нових підприємств, збільшуючи фінансовий леверидж. 3 цієї причини в умовах економічного спаду та зростання вартості позикового капіталу фінансова стійкість агрохолдингів може знижуватись. Тому важливою науковою задачею $є$ дослідження динаміки розвитку, фі- нансового стану та структури капіталу провідних агрохолдингів країни.

Аналіз останніх публікацій 3 проблеми. Дослідженню особливостей розвитку вертикально інтегрованих агрохолдингів присвячені наукові роботи таких зарубіжних та вітчизняних вчених, як S. Aggelopoulos, V. Samathrakis [3], W. Jozwiak, Z. Mirkowska [4], Z. Kroupová [5], E. J. Szymańska [6], G. Trnková, Z. Malá [7], Н.M. Давиденко [8], C.M. Дідус [9], І.М. Зеліско [10], К.Б. Мельник [11], Г. Черевко [12], Р. Хірівський, Р. Дудяк, Т. Гачек [13]. Однак недостатньо вивченим $є$ питання зміни фінансового стану агрохолдингів в умовах несприятливої ринкової кон'юнктури.

Формулювання цілей дослідження. Основною метою статті є дослідження особливостей розвитку, фінансового стану та структури капіталу провідних агрохолдингів країни в умовах несприятливого макроекономічного середовища.

Виклад основних результатів та їх обгрунтування. Агрохолдингом прийнято вважати групу юридичних, самостійних сільськогосподарських, переробних і обслуговуючих організацій, контрольні пакети статутних капіталів яких належать одній особі [14]. Інформація про провідні агрохолдинги України представлена у табл. 1 .

Інформація про найбільші агрохолдинги України

\begin{tabular}{|l|l|c|}
\hline \multicolumn{1}{|c|}{$\begin{array}{c}\text { Назва } \\
\text { агрохолдингу }\end{array}$} & \multicolumn{1}{|c|}{ Вид діяльності } & $\begin{array}{c}\text { Площа угідь, } \\
\text { тис. га }\end{array}$ \\
\hline Ukrlandfarming & $\begin{array}{l}\text { Виробництво зернових культур і насіння, виробництво ясць, цукру, } \\
\text { тваринництво, трейдинг і дистрибуція сільськогосподарської про- } \\
\text { дукції }\end{array}$ & 654 \\
\hline $\begin{array}{l}\text { New Century } \\
\text { Holding (NCH) }\end{array}$ & Виробництво зернових культур і насіння, тваринництво & 420 \\
\hline
\end{tabular}




\begin{tabular}{|l|l|c|} 
Kernel & $\begin{array}{l}\text { Виробництво соняшникової олії, виробництво зерна, портові термі- } \\
\text { нали, послуги елеваторів, сільське господарство }\end{array}$ & 389 \\
\hline $\begin{array}{l}\text { Миронівський хлі- } \\
\text { бопродукт }\end{array}$ & $\begin{array}{l}\text { Виробництво зернових культур і насіння, птахівництво, виробни- } \\
\text { цтво олії, вирощування овочів і фруктів }\end{array}$ & 290 \\
\hline Астарта-Київ & $\begin{array}{l}\text { Вирощування буряку, зернових і олійних культур, виробництво } \\
\text { цукру та супутньої продукції, а також молока і м’яса }\end{array}$ & 245 \\
\hline $\begin{array}{l}\text { Українські аграрні } \\
\text { інвестиції }\end{array}$ & Сільськогосподарське виробництво & 261 \\
\hline
\end{tabular}

У якості об'єктів дослідження нами були обрані два агрохолдинги, які не тільки займають провідну позицію на українському ринку, але й активно експортують продукцію: MHP S.A. ("Миронівський хлібопродукт") і Kernel Holding S.A. Цінні папери цих компаній котируються на європейських фондових біржах (табл. 2).

Характеристика MHP S.A. тa Kernel Holding S.A.*

\begin{tabular}{|c|c|c|}
\hline & Kernel & MHP \\
\hline Площа земельних угідь, тис. га & 390 & 320 \\
\hline Сегменти діяльності & $\begin{array}{c}\text { виробництво соняшникової олії, } \\
\text { виробництво бутильованої олії, } \\
\text { виробництво зерна, портові те- } \\
\text { рмінали, послуги елеваторів, } \\
\text { сільське господарство }\end{array}$ & $\begin{array}{c}\text { рослинництво та виробництво } \\
\text { кормів, птахівництво, переро- } \\
\text { бка м'яса, виробництво соня- } \\
\text { шникової олії, вирощування } \\
\text { овочів і фруктів } \\
\end{array}$ \\
\hline Країна реєстрації & Люксембург & Люксембург \\
\hline Біржа, на якій розміщено акції & Варшавська фондова біржа & Лондонська фондова біржа \\
\hline $\begin{array}{l}\text { Дохід від реалізації за } 2014 \text { рік, млн. } \\
\text { доларів США }\end{array}$ & 2487 & 1379 \\
\hline $\begin{array}{l}\text { Прибуток від операційної діяльності за } \\
2014 \text { рік, млн. доларів США }\end{array}$ & 304,27 & 460 \\
\hline Рентабельність операційної діяльності & $12,2 \%$ & $33,4 \%$ \\
\hline EBITDA за 2014 рік, млн. доларів США & 385,2 & 555 \\
\hline $\begin{array}{l}\text { Чистий прибуток за } 2014 \text { рік, млн. до- } \\
\text { ларів США }\end{array}$ & 22,5 & -412 \\
\hline
\end{tabular}

* Розрахунки автора на основі даних звітності за 2014 фінансовий рік та 1 півріччя 2015 фінансового року $[15,16,17]$

На сьогоднішній день Kernel Holding S.A. провідна диверсифікована агропромислова компанія, що веде свою діяльність в Україні, а також в Росії.

Діяльність компанії зосереджена в шести бізнес-сегментах:

- виробництво соняшникової олії - компанія $\epsilon$ найбільшим в Україні виробником і експортером соняшникової олії із часткою $13 \%$ світового ринку за підсумком 2013/2014 маркетингового року;

- виробництво бутильованої олії - для реалізації на внутрішньому ринку України під власними торгівельними марками;
- виробництво зерна;

- портові термінали;

- послуги елеваторів - найбільша приватна мережа зернових елеваторів в Україні загальною потужністю одноразового зберігання 2,8 мільйонів тонн;

- $\quad$ сільське господарство - 390000 гектарів посівних площ.

За підсумками 2014 фінансового року у структурі доходів від реалізації Kernel Holding S.A. 44,7 \% належить соняшниковій олії (у тому числі бутильованій олії), 38,9\% - реалізації зерна (рис. 1). 


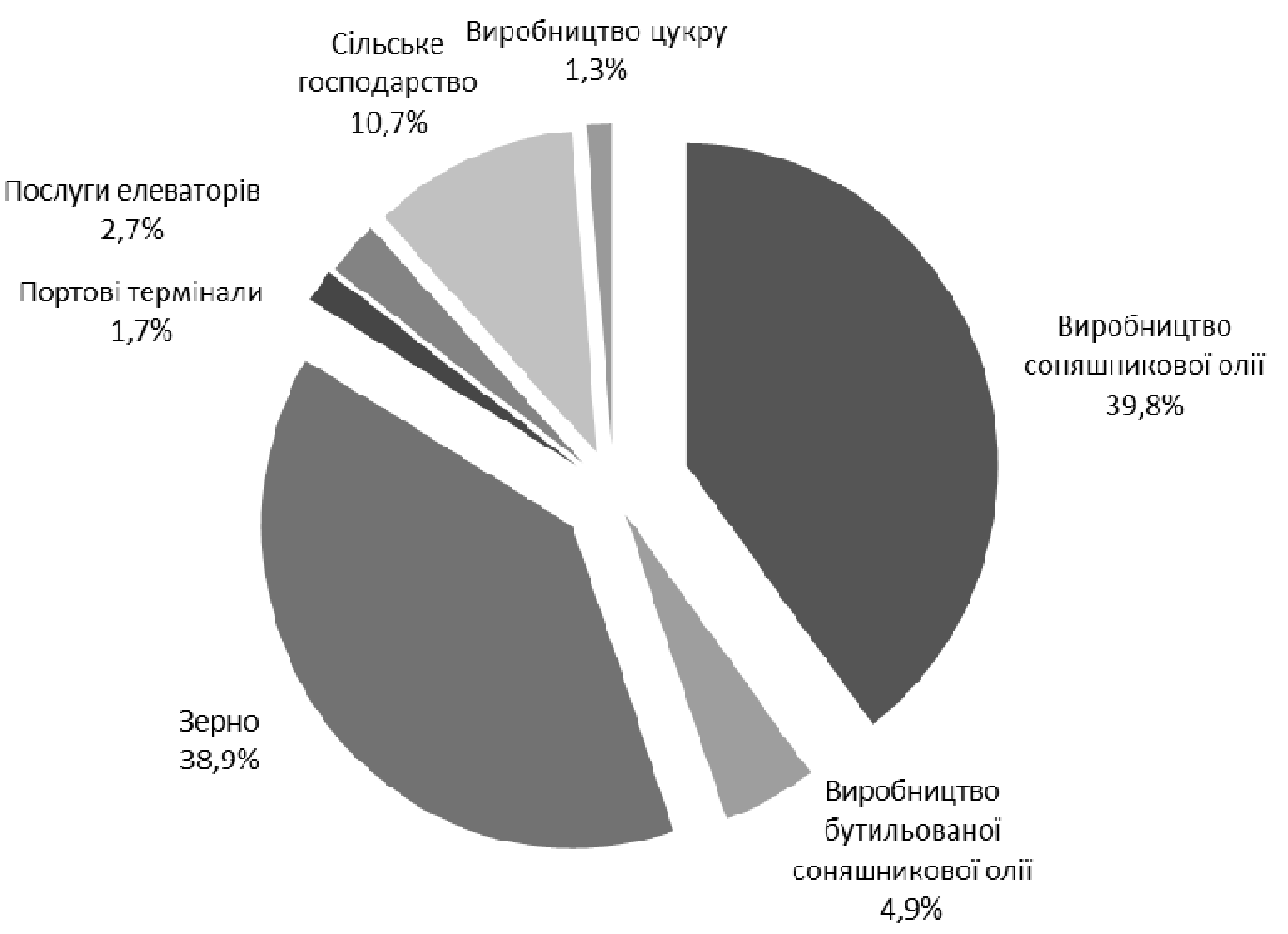

Рис. 1. Структура доходів від реалізації Kernel Holding S.A. у 2014 фінансовому році $[15,16]$

Kernel Holding S.A. $є$ провідним експортером соняшникової олії і шроту та одним 3 найбільших експортерів зернових з чорноморського регіону, щорічно постачаючи на міжнародний ринок близько 6 млн. тонн сільськогосподарської продукції [16].

MHP S.A. ("Миронівський хлібопродукт") одна з провідних агропромислових компаній в Україні, діяльність якої зосереджена на виробництві м'яса птиці та вирощуванні зернових. До складу MHP S.A. входять 20 підприємств, розташованих у Київській, Черкаській, Дніпропетровській, Донецькій, Вінниць- кій, Івано-Франківській, Херсонській областях та АР Крим. Підприємства створюють замкнутий цикл м'ясного виробництва: вирощування зернових, виготовлення комбікормів, вирощування батьківського поголів'я худоби, виробництва і переробки м'яса. Окрім того, підприємства холдингу займаються виробництвом соняшникової олії, а також вирощуванням овочів і фруктів. Втім за підсумками 2014 року 67,4 \% доходів від реалізації припадає на м'ясо птиці та іншу продукцію, ще 17,9 \% - на соняшникову олію (рис. 2).

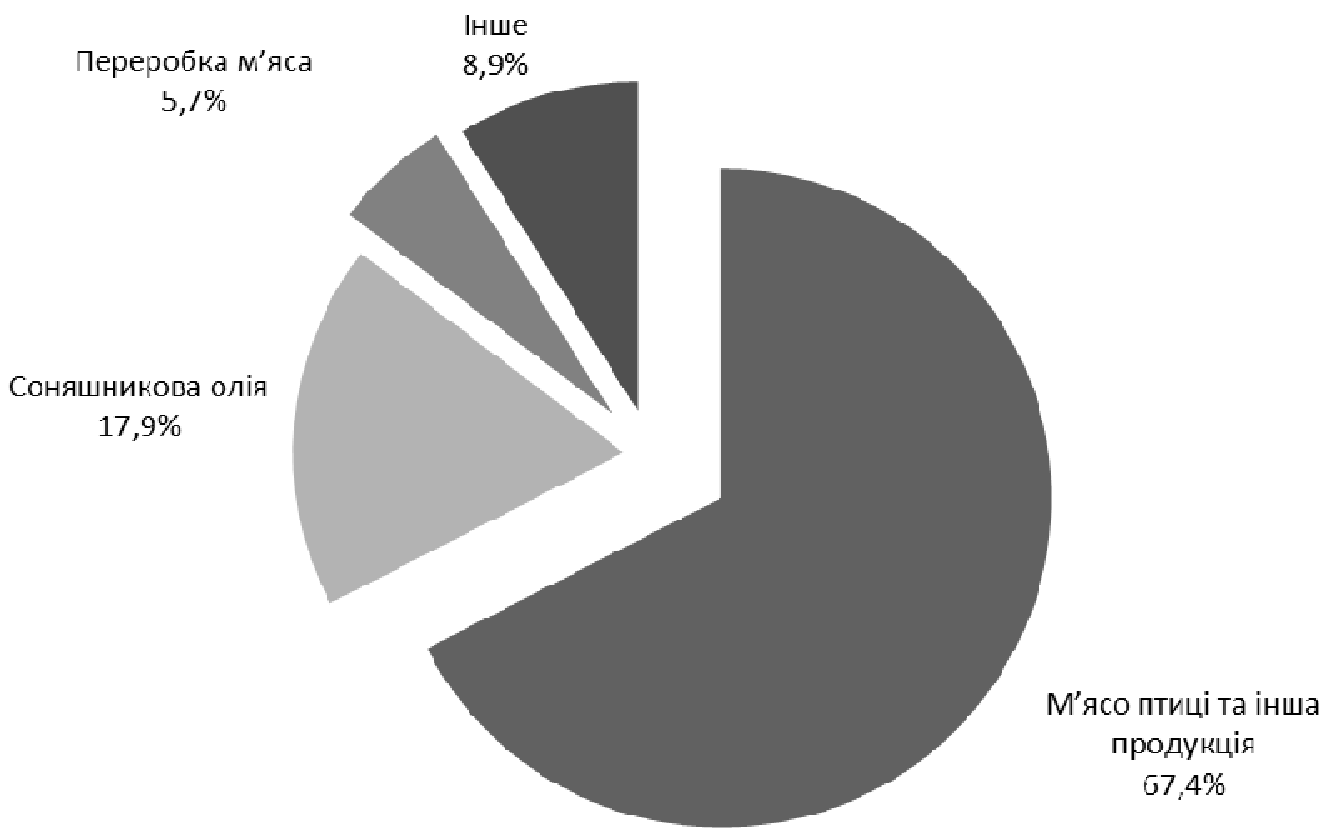

Рис. 2. Структура доходів від реалізації МНP S.А. у 2014 році [17] 
Стратегія розвитку Kernel Holding S.A. та MHP S.A., як й інших агрохолдингів країни, впродовж останніх 10 років передбачала активну інвестиційну політику: придбання нових активів в Україні та за іiі межами, будівництво нових підприємств та розбудову інфраструктури. Фінансування цих проектів відбувалось в першу чергу за рахунок позикового капіталу у розрахунку на стабільне та довготривале зростання компаній.

Однак економічна кон'юнктура негативно вплинула на фінансові показники компаній у 2014 році. Основними причинами цього $є$ девальвація гривні, тимчасова втрата частини території країни, падіння купівельної спроможності населення, зменшення експорту до країн Митного союзу, припинення виробництва у зоні бойових дій. Наприклад, у 2014 році MHP S.A. призупинила операційну діяльність птахофабрики „Шахтарська“ (Донецька обл.), яка виробляла $30 \%$ інкубаційних яєць компанії.

Як наслідок, відбулось зниження фінансових результатів агропромислових компаній. Дохід від реалізації Kernel Holding S.A. у 2014 фінансовому році (із 1.07.2013 р. по 31.06.2014 р.) склав 2393,3 млн. доларів США, що на 14,4 \% менше, ніж у попередньому році (рис. 3).

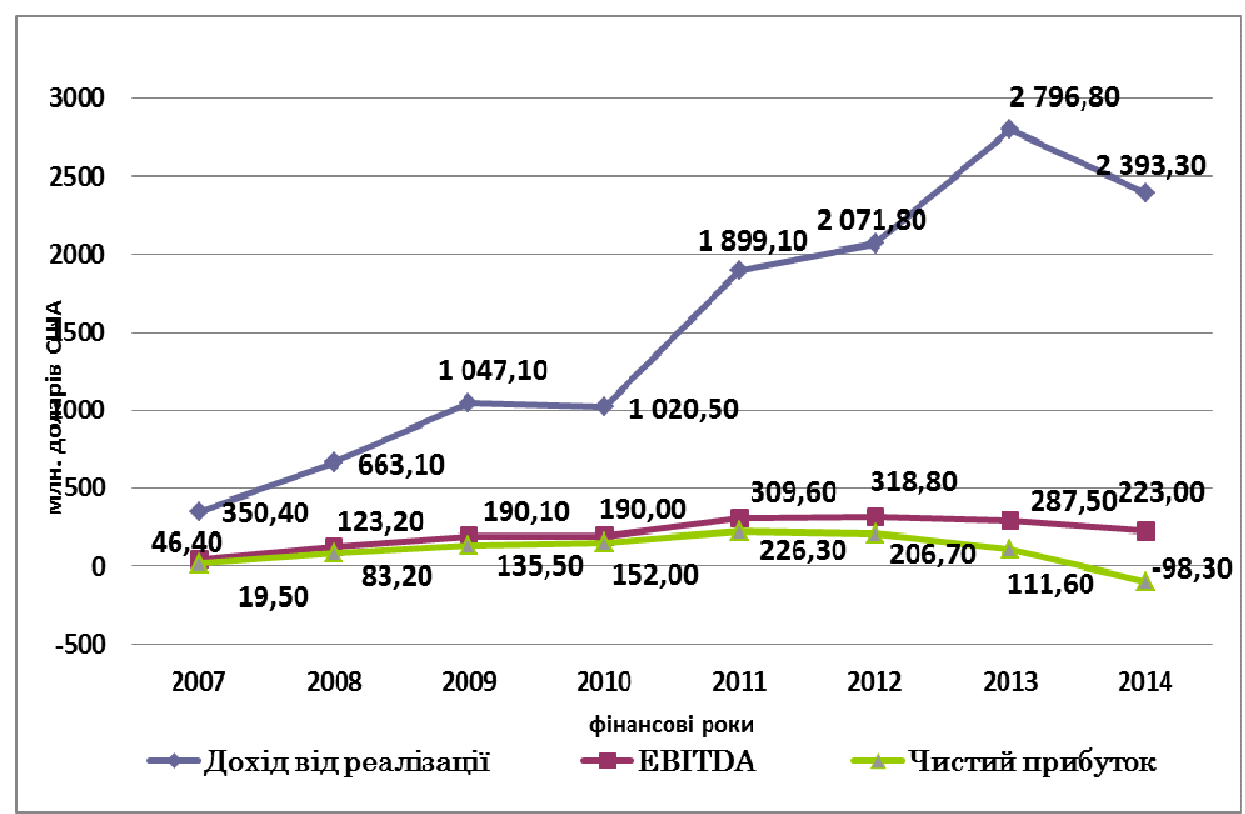

Рис. 3. Динаміка фінансових показників Kernel Holding S.A. у 2007-2014 фінансових роках $[15,16]$

EBITDA компанії зменшилась на $22,4 \%$ - до 223 млн. доларів США. Чистий збиток за 2014 фінансовий рік склав 98,3 млн. доларів США - у першу чергу через збитки від курсової різниці та інші витрати. Діяльність Kernel Holding S.A. вперше була збитковою із 2007 року.
Доход від реалізації МНP S.A. знизився у 2014 році у порівнняні із 2013 роком на 7,8 \% при зростанні EBITDA на 41,9\%. Чистий збиток компанії склав 412 млн. доларів США (рис. 4).

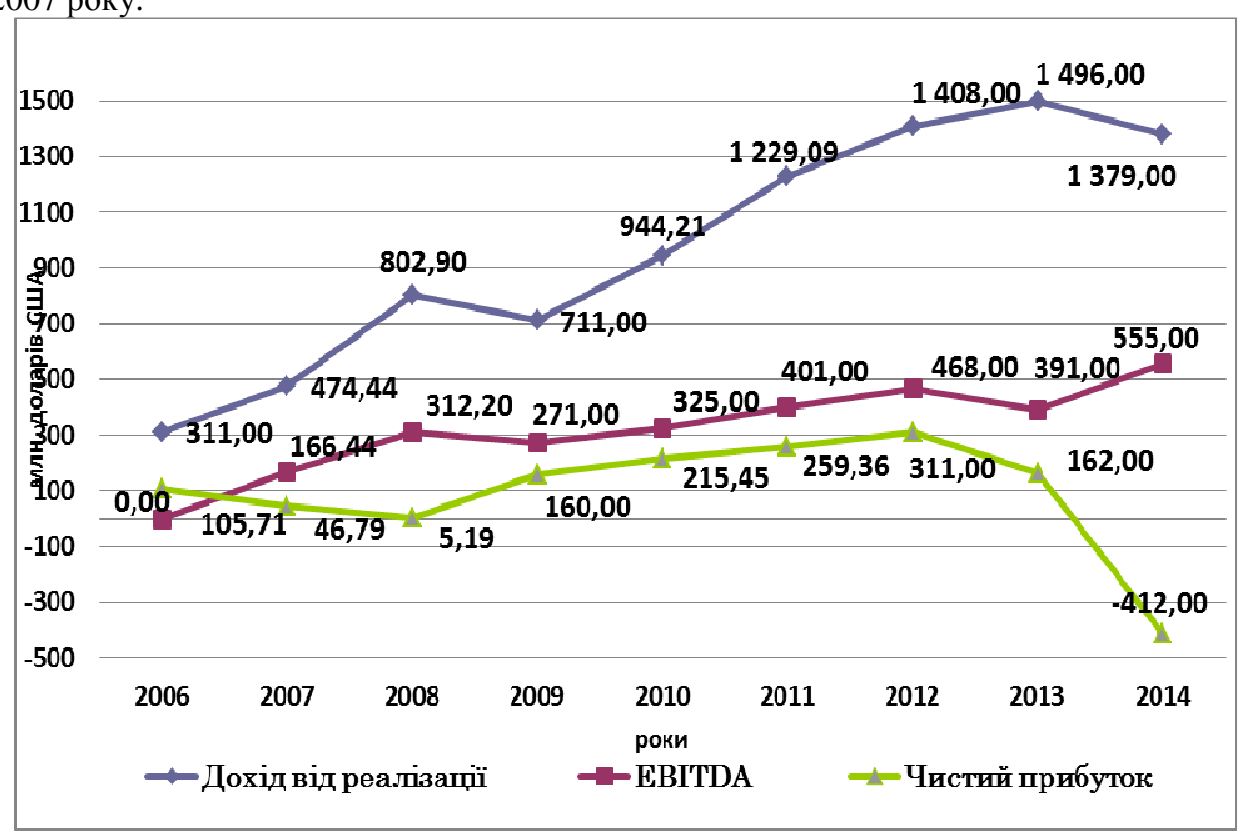

Рис. 4. Динаміка фінансових показників МНP S.A. у 2006-2014 роках [17] 
Зниження фінансових показників та зростання ризиків негативно відобразилось на вартості акцій обох компаній. Вартість глобальних депозитарних розписок (GDR) MHP S.A., еквівалентних 1 простій акції, знизилась із 17,75 долларів США на 1.01.2014 до 9,2 долларів США на 1.01.2015, тобто на 48,2 \% за рік [18]. Вартість 1 акції
Kernel Holding S.A. на Варшавській фондовій біржі за цей же період знизилась із 42,83 злотих до 28,46 злотих («мінус» 33,6 \%) [19].

Активи Kernel Holding S.A. впродовж 2014 року зменшились на 639,804 млн. доларів США, або на $24,9 \%$ (табл. 3 ).

Аналіз структури активів та пасивів Kernel Holding S.A.*

Таблиця 3

\begin{tabular}{|c|c|c|c|c|c|c|}
\hline \multicolumn{7}{|c|}{ Активи } \\
\hline & \multicolumn{2}{|c|}{ на 31.12.2013 } & \multicolumn{2}{|c|}{ на 31.12.2014 } & \multicolumn{2}{|c|}{ Відхилення } \\
\hline & значення & структура & значення & Структура & значення & структура \\
\hline Необоротні активи & 1212,739 & $47,1 \%$ & 950,639 & $49,2 \%$ & $-262,1$ & $2,04 \%$ \\
\hline Оборотні активи & 1361,091 & $52,9 \%$ & 983,387 & $50,8 \%$ & $-377,704$ & $-2,04 \%$ \\
\hline Баланс & 2573,83 & $100,0 \%$ & 1934,026 & $100,0 \%$ & $-639,804$ & \\
\hline \multicolumn{7}{|c|}{ Пасиви } \\
\hline & \multicolumn{2}{|c|}{ на 31.12.2013 } & \multicolumn{2}{|c|}{ на 31.12.2014 } & \multicolumn{2}{|c|}{ Відхилення } \\
\hline & значення & структура & значення & Структура & значення & структура \\
\hline Власний капітал & 1304,469 & $50,7 \%$ & 980,33 & $50,7 \%$ & $-324,139$ & $0,01 \%$ \\
\hline Короткострокові зобов'язання & 910,226 & $35,4 \%$ & 754,864 & $39,0 \%$ & $-155,362$ & $3,67 \%$ \\
\hline Довгострокові зобов'язання & 359,135 & $14,0 \%$ & 198,832 & $10,3 \%$ & $-160,303$ & $-3,67 \%$ \\
\hline Баланс & 2573,83 & $100,0 \%$ & 1934,026 & $100,0 \%$ & $-639,804$ & \\
\hline
\end{tabular}

*Розраховано автором за даними фінансової звітності корпоративних підприємств $[15,16,17]$

Відбулось скорочення балансової вартості необоротних активів на 262,1 млн. доларів США (на $21,6 \%$ ), оборотних активів - на 377,704 млн. доларів США (на 27,8\%). У структурі пасивів зросла частка короткострокових зобов'язань за рахунок зменшення частки довгострокових зобов'язань

Балансова вартість активів MHP S.A. у 2014 році скоротилась на 474,59 млн. доларів США, або на $17,1 \%$ (табл. 4).

Аналіз структури активів та пасивів MHP S.A.*

Таблиця 4

\begin{tabular}{|c|c|c|c|c|c|c|}
\hline \multicolumn{7}{|c|}{ Активи } \\
\hline & \multicolumn{2}{|c|}{ на 31.12.2013 } & \multicolumn{2}{|c|}{ на 31.12.2014 } & \multicolumn{2}{|c|}{ Відхилення } \\
\hline & значення & структура & значення & Структура & значення & структура \\
\hline Необоротні активи & 1658,912 & $59,9 \%$ & 1561,669 & $68,1 \%$ & $-97,243$ & $8,16 \%$ \\
\hline Оборотні активи & 1109,166 & $40,1 \%$ & 731,819 & $31,9 \%$ & $-377,347$ & $-8,16 \%$ \\
\hline Баланс & 2768,078 & $100,0 \%$ & 2293,488 & $100,0 \%$ & $-474,59$ & \\
\hline \multicolumn{7}{|c|}{ Пасиви } \\
\hline & \multicolumn{2}{|c|}{ на 31.12.2013 } & \multicolumn{2}{|c|}{ на 31.12.2014 } & \multicolumn{2}{|c|}{ Відхилення } \\
\hline & значення & структура & значення & Структура & значення & структура \\
\hline Власний капітал & 1249,205 & $45,1 \%$ & 945,522 & $41,2 \%$ & $-303,683$ & $-3,90 \%$ \\
\hline Короткострокові зобов’язання & 328,435 & $11,9 \%$ & 428,265 & $18,7 \%$ & 99,83 & $6,81 \%$ \\
\hline Довгострокові зобов'язання & 1190,438 & $43,0 \%$ & 919,701 & $40,1 \%$ & $-270,737$ & $-2,91 \%$ \\
\hline Баланс & 2768,078 & $100,0 \%$ & 2293,488 & $100,0 \%$ & $-474,59$ & \\
\hline
\end{tabular}

*Розраховано автором за даними фінансової звітності корпоративних підприємств $[15,16,17]$

На основі звітів компаній [15-17], проведено експрес-дослідження фінансової стійкості даних агрохолдингів та діагностику загрози банкрутства за системою показників Бівера [20-21]. Результати до- слідження (табл. 5) свідчать про те, що фінансова стійкість MHP S.A. у 2014 році знизилась - погіршились значення усіх коефіцієнтів, що входять до системи показників Бівера. 
Результати експрес-дослідження фінансової стійкості MHP S.A. та Kernel Holding S.A. за системою показників У. Бівера*

\begin{tabular}{|l|c|c|c|c|c|c|c|c|}
\hline \multirow{2}{*}{\multicolumn{1}{|c|}{ Показники }} & \multicolumn{4}{|c|}{ Kernel Holding S.A } & \multicolumn{4}{c|}{ MНP S.А. } \\
\cline { 2 - 11 } & \multicolumn{2}{|c|}{2013 рік } & \multicolumn{2}{c|}{2014 рік } & \multicolumn{2}{c|}{2013 рік } & \multicolumn{2}{c|}{2014 рік } \\
\cline { 2 - 11 } & значення & 3она & 3начення & зона & значення & зона & значення & зона \\
\hline Коефіцієнт Бівера & 0,111 & $\mathrm{~B}$ & 0,109 & $\mathrm{~B}$ & 0,185 & $\mathrm{~B}$ & 0,040 & $\mathrm{~B}$ \\
\hline $\begin{array}{l}\text { Коефіцієнт рентабельності ак- } \\
\text { тивів,\% }\end{array}$ & $-0,023$ & $\mathrm{C}$ & 1,163 & $\mathrm{~B}$ & 5,85 & $\mathrm{~A}$ & $-17,96$ & $\mathrm{C}$ \\
\hline $\begin{array}{l}\text { Коефіцієнт фінансового «важе- } \\
\text { ля» }\end{array}$ & 0,493 & $\mathrm{~B}$ & 0,493 & $\mathrm{~B}$ & 0,549 & $\mathrm{C}$ & 0,588 & $\mathrm{C}$ \\
\hline $\begin{array}{l}\text { Коефіцієнт покриття активів } \\
\text { чистим оборотним капіталом }\end{array}$ & 0,036 & $\mathrm{C}$ & 0,015 & $\mathrm{C}$ & $-0,148$ & $\mathrm{C}$ & $-0,269$ & $\mathrm{C}$ \\
\hline Коефіцієнт покриття & 1,495 & $\mathrm{~B}$ & 1,303 & $\mathrm{~B}$ & 3,804 & $\mathrm{~A}$ & 2,208 & $\mathrm{~A}$ \\
\hline
\end{tabular}

*Розраховано автором за даними фінансової звітності корпоративних підприємств $[15,16,17]$

За трьома показниками із п'яти MHP S.A. входить до зони С, до якої відносяться підприємства, що знаходяться за 1 рік до банкрутства. Відповідає нормативним значенням лише коефіцієнт покриття, значення якого перебуває у межах зони А (стійка, прибуткова компанія).

Kernel Holding S.A., відповідно до проведених розрахунків, має кращий фінансовий стан, проте за чотирма коефіцієнтами компанія знаходиться у зоні В (підприємства за 5 років до банкрутства) та за одним - у зоні С.

Зважаючи на важливе значення обох агрохолдингів для економіки України, зниження їх фінансової стійкості є загрозливою тенденцією, яка у перспективі може негативно вплинути на інші компанії та цілі сектори національної економіки. Однак, на нашу думку, у довгостроковій перспективі ймовірність банкрутства обох компаній є невисокою. Це пояснюється тим, що вони мають диверсифіковану структуру бізнесу, довгострокову інвестиційну стратегію та во- лодіють механізмами управління вертикально інтегрованими структурами в умовах несприятливої ринкової кон'юнктури.

Висновки та перспективи подальших досліджень. Несприятливі макроекономічні зміни в економіці України негативно вплинули на фінансові результати агрохолдингів та їх фінансову стійкість. Пріоритетними напрямками розвитку для вертикально інтегрованих агропромислових компаній, як ми бачимо на прикладі Kernel Holding S.A. і MHP S.A., мають стати оптимізація структури капіталу, підвищення рентабельності операційної діяльності за рахунок оптимізації витрат. Українські агрохолдинги у середньостроковій перспективі мають бути націлені на використання можливостей завоювання нових ринків збуту, у першу чергу ринку країн ЄС. При цьому питання оцінювання фінансового стану та оптимальної структури капіталу агрохолдингів в сучасних умовах потребує подальшого грунтовного наукового дослідження.

\section{Література}

1. Андрійчук В. Г. Агропромислові формування нового типу в контексті стратегії розвитку вітчизняного сільського господарства / В. Г. Андрійчук // Економіка АПК. - 2013. - №1 - - С. 3-15.

2. Найбільші агрохолдинги України: щорічне дослідження агенції AgriSurvey [Електронний ресурс] // Режим доступу : http://http://agrisurvey.com.ua/images/files/multi_client/analitics_surv/Agriholdings2014ua _demo.pdf (30.03.15). — Назва з екрану.

3. Aggelopoulos S., Samathrakis V., Theocharopoulos A. Determination of the economic viability level of agricultural holdings based on socio-economic parameters / S. Aggelopoulos, V. Samathrakis, A. Theocharopoulos [Електронний ресурс] // Режим доступу : http://sbagis.farm.teithe.gr/uploads/8/3/4/5/8345585/sbagis_a4_18.pdf.

4. Józwiak W., Mirkowska Z. Polish agricultural holdings in the first years of the EU membership / W. Józwiak, Z. Mirkowska [Електронний pecypc] // Режим доступу : http://depot.ceon.pl/bitstream/handle/ 123456789/5775/J\% C3\%B3zwiak\%20Mirkowska.pdf?sequence=1\&isAllowed=y.

5. Kroupová Z., Trnková G. The analysis of economic results differences of agricultural holdings specialized in plant production in the Czech Republic / Z. Kroupová, G. Trnková // Journal of Central European Agriculture, 2014, 15(3), p.322-334.

6. Szymańska E. J. The importance of financial support for Polish agricultural holdings under common agricultural policy / E. J. Szymańska [Електронний ресурс] // Режим доступу : http://journals.nubip.edu.ua/ index.php/Economica/article/download/527/502

7. Trnková, G., Malá, Z. Analysis of distribution impact of subsidies within the Common Agricultural Policy on field production businesses in the Czech Republic / G. Trnková, Z. Malá // Acta Universitatis Agriculturae et Silviculturae Mendelianae Brunensis, LX (7), 415 - 424. 
8. Давиденко Н. М. Оцінка фінансового стану підприємств корпоративного типу в агробізнесі України / Н. М. Давиденко // Облік і фінанси. - 2012. — № 1. - С. 111-117.

9. Дідус С. М. Агрохолдинги в Україні: особливості становлення та розвитку [Текст] / С. М. Дідус // Економіка АПК : Міжнародний науково-виробничий журнал. — 2011. — N 12. - С. 96-101.

10. Зеліско І. М. Особливості формування і використання фінансових ресурсів аграрних холдингів / I. М. Зеліско [Електронний ресурс] // Режим доступу: http://elibrary.kubg.edu.ua/7740/1/I_Zelisko_EE_11_IS.pdf.

11. Мельник К. Б. Фінансове забезпечення функціонування агрохолдингів в сучасних умовах. / К. Б. Мельник // Науковий вісник Національного університету біоресурсів і природокористування України. Сер. : Економіка, аграрний менеджмент, бізнес. - 2013. - Вип. 181(5). — С. 57-66. — Режим доступу : http://nbuv.gov.ua/j-pdf/nvnau_econ_2013_181(5)__10.pdf

12. Черевко Г. Агрохолдинги як нові організаційні форми крупнотоварного господарювання в агробізнесі України / Г. Черевко // Аграрна економіка. - 2012. - Т. 5, № 1-2. - С. 36-42. — Режим доступу : http://nbuv.gov.ua/j-pdf/ae_2012_5_1-2_9.pdf.

13. Хірівський Р. Діяльність агрохолдингів в Україні та напрями їх розвитку / Р. Хірівський, Р. Дудяк, Т. Гачек // Вісник Львівського національного аграрного університету. Сер : Економіка АПК. — 2013. № 20(1). — С. 65-72. — Режим доступу : http://nbuv.gov.ua/j-pdf/Vlnau_econ_2013_20(1)_13.pdf.

14. Садчиков В. С. Науково-методичні підходи до формування нових організаційних структур в аграрному секторі економіки / В. С. Садчиков // Вісник Чернігівського державного технологічного університету. Серія : Економічні науки. - 2013. - № 4. - С. 296-304. - Режим доступу : http://economicvistnic.stu.cn.ua/index.pl?task=arcls\&id=1160.

15. Kernel Holding S.A. and Subsidiaries Condensed Consolidated Interim Financial Statements for 6 months ended 31 December 2014 [Електронний ресурс] - Режим доступу : http://www.kernel.ua/media/uploads/library/ 14/10/KERNEL_FY_2014_Annual_Report.pdf.

16. Kernel Holding S.A. Annual Report and Accounts 30 June 2014 [Електронний ресурс] - Режим доступу : http ://www.kernel.ua/ media/uploads/library/14/10/KERNEL_FY_2014_Annual_Report.pdf.

17. MHP S.A. Фінансові результати за четвертий квартал і дванадцять місяців, які закінчилися 31 грудня 2014 року [Електронний ресурс] - Режим доступу: www.mhp.com.ua/library/file/mhp-14fsu-final-ua.pdf.

18. MHP S.A. на сайті Лондовської фондової біржі [Електронний ресурс] - Режим доступу : http://www.londonstockexchange.com/exchange/prices-and-markets/stocks/summary/company-summary/55302T2042 USUSDIOBE.html.

19. Kernel Holding S.A. на сайті Варшавської фондової біржі [Електронний ресурс] - Режим доступу : http://www.gpw.pl/karta_spolki/LU0327357389/.

20. William H. Beaver. Financial ratios as predictors of failure, empirical research in accounting selected studies // Supplement to Journal of Accounting Research. — 1966. — N4. — PP. 71-111.

21. Посохов I. М. Використання системи показників У. Бівера для оцінки ризику банкрутства корпорацій / І. М. Посохов // Вісник СумДУ. Серія “Економіка”. - 2013. - №3. - С. 65- 72.

Стаття надійшла 01.09.2015

\author{
Дидух С.M. \\ кандидат экономических наук \\ кафедра экономики промышленности \\ Одесская национальная академия пищевых технологий \\ ул. Канатная, 112, г. Одесса, Украина, 65039 \\ E-mail: didukhsm@i.ua
}

\title{
ОЦЕНКА ФИНАНСОВОГО СОСТОЯНИЯ И ДИНАМИКИ РАЗВИТИЯ АГРОХОЛДИНГОВ УКРАИНЫ
}

Агрохолдинги являются важной частью экономики Украины. Они играют значительную роль во внедрении инновационных технологий, росте урожайности, увеличении экспорта продуктов питания. Проблема обеспечения стабильного развития агрохолдингов в условиях неблагоприятной рыночной конъюнктуры остается недостаточно исследованной. Поэтому актуальной научной задачей является изучение динамики развития, проблем и перспектив агрохолдингов в условиях экономического кризиса в Украине.

Целью статьи является исследование особенностей развития, фринансового состояния и структуры капитала ведущих агрохолдингов страны в условиях неблагоприятной макроэкономической среды. Объектами исследования являются агрохолдинги MHP SA и Kernel Holding S.A. 
Проанализирована динамика финансовых показателей агрохолдингов Украины на примере Kernel Holding SA и MHP S.A. Исследована структура доходов компаний, динамика финансовых показателей и структура капитала. Проведено экспресс-исследование финансовой устойчивости данных компаний по системе показателей У. Бивера.

Указаны причины снижения фринансовых результатов компаний: девальвация гривны, временная потеря части территории страны, падение покупательной способности населения, сокращение экспорта в страны Таможенного союза, прекращение производства в зоне боевых действий. Определено, что произошло снижение капитала агрохолдингов, падение стоимости их акций, а также снижение коэффициентов финансового состояния компаний.

Обосновано, что ключевыми направлениями развития агропромышленных компаний должны стать оптимизация структуры капитала, повышение рентабельности операционной деятельности за счет оптимизации расходов.

Ключевые слова: агрохолдинг, Kernel Holding SA, MHP SA, фринансовое состояние, структура капитала, система показателей У. Бивера.

\author{
Didukh S.M. \\ Ph.D. in Economics \\ Department of Industrial Economics \\ Odessa National Academy of Food Technologies \\ Kanatna Street, 112, Odessa, Ukraine, 65039 \\ E-mail: didukhsm@i.ua
}

\title{
EVALUATION OF THE FINANCIAL CONDITION AND DYNAMICS OF DEVELOPMENT OF AGRICULTURAL HOLDINGS IN UKRAINE
}

Agricultural holdings are an important part of the Ukraine's economy. They take on enormous importance in adoption of innovative technology, increasing productivity, increasing exports of food products. The problem of sustainable development of agricultural holdings in the unfavorable market conditions is not sufficiently investigated. Therefore, actual scientific task is to study the dynamics of development, problems and prospects of agricultural holdings in the economic crisis in Ukraine.

The main purpose of the article is to study the characteristics of development, financial position and capital structure the Ukraine's leading agricultural holdings in a volatile macroeconomic environment. The objects of study are agribusiness holding companies MHP S.A. and Kernel Holding S.A.

The dynamics of financial indicators Ukraine's agribusiness holding companies by the example of Kernel Holding SA and MHP S.A has been analyzed in the article. The structure of corporate earnings, the dynamics of the financial results and capital structure has been investigated in the article. Research of financial stability of companies with the help of financial ratios of William $\mathrm{H}$. Beaver was conducted.

We have indicated the reasons for the decline of the financial results of companies, such as the sharp devaluation of the Ukrainian hryvnya, temporary loss of territory, falling of the purchasing power in Ukraine, reducing of export to countries of the Customs Union, the depression of production in region of combat operations. We determined that there has been the decreasing of agribusiness companies' capital, the decreasing in the value of their shares and reduction of ratios of the financial situation of companies.

We substantiated that the key direction for the development agribusiness holding companies should be optimization of capital structure, improving the profitability of operations by optimizing costs.

Keywords: agricultural holding, Kernel Holding SA, MHP SA, financial position, capital structure, a system of indicators W. Beaver.

\section{References}

1. AndrIychuk, V.G. (2013). Agropromislovi formuvannya novogo tipu v konteksti strategiyi rozvitku vitchiznyanogo silskogo gospodarstva. EkonomIka APK, 1, 3-15.

2. Najbiljshi aghrokholdynghy Ukrajiny: shhorichne doslidzhennja aghenciji AgriSurvey Retrieved from http://http://agrisurvey.com.ua/images/files/multi_client/ analitics_surv/ Agriholdings2014ua_demo.pdf (30.03.15).

3. Aggelopoulos, S., Samathrakis, V., Theocharopoulos, A. (2007). Determination of the Economic Viability Level of Agricultural Holdings Based on Socio-Economic Parameters. Proceedings of the 4th AFE Conference, Samos Island, 12-14 July 2007. 
4. Józwiak W., Mirkowska Z. (2010). Polish agricultural holdings in the first years of the EU membership Retrieved from http://depot.ceon.pl/bitstream/handle/123456789/5775/J\%C3\%B3zwiak\%20Mirkowska.pdf?Sequence $=1 \&$ is Allowed $=\mathrm{y}$.

5. Kroupová, Z., Trnková, G. (2014). The analysis of economic results differences of agricultural holdings specialized in plant production in the Czech Republic./ Z. Kroupová, G. Trnková // Journal of Central European Agriculture, 15(3), 322-334.

6. Szymańska, E. J. (2013). The importance of financial support for Polish agricultural holdings under common agricultural policy. Retrieved from http://journals.nubip.edu.ua/index.php/Economica/article/download/ $527 / 502$.

7. Trnková, G., Malá, Z. (2012). Analysis of distribution impact of subsidies within the Common Agricultural Policy on field production businesses in the Czech Republic. Acta Universitatis Agriculturae et Silviculturae Mendelianae Brunensis, LX (7), 415- 424.

8. Davydenko, N. M. (2012). Ocinka finansovogho stanu pidpryjemstv korporatyvnogho typu v aghrobiznesi Ukrajiny. Oblik i finansy, 1, 111-117.

9. Didus, S. M. (2011). Aghrokholdynghy v Ukrajini: osoblyvosti stanovlennja ta rozvytku. Ekonomika APK : Mizhnarodnyj naukovo-vyrobnychyj zhurnal, 12, 96-101.

10. Zelisko, I. M. (2014). Osoblyvosti formuvannja i vykorystannja finansovykh resursiv aghrarnykh kholdynghiv. Retrieved from: http://elibrary.kubg.edu.ua/7740/1/I_Zelisko_EE_11_IS.pdf.

11. Meljnyk, K. B. (2013). Finansove zabezpechennja funkcionuvannja aghrokholdynghiv v suchasnykh umovakh. Naukovyj visnyk Nacionaljnogho universytetu bioresursiv i pryrodokorystuvannja Ukrajiny. Ser. : Ekonomika, aghrarnyj menedzhment, biznes, 181(5), 57-66.

12. Cherevko, Gh. (2012). Aghrokholdynghy jak novi orghanizacijni formy krupnotovarnogho ghospodarjuvannja v aghrobiznesi Ukrajiny. Aghrarna ekonomika, vol. 5, 1-2, 36-42.

13. Khirivsjkyj, R., Dudjak, R., Ghachek, T. (2013). Dijaljnistj aghrokholdynghiv v Ukrajini ta naprjamy jikh rozvytku. Visnyk Ljvivsjkogho nacionaljnogho aghrarnogho universytetu. Ser : Ekonomika APK, 20(1), 65-72.

14. Sadchykov, V. S. (2013). Naukovo-metodychni pidkhody do formuvannja novykh orghanizacijnykh struktur v aghrarnomu sektori ekonomiky. Visnyk Chernighivsjkogho derzhavnogho tekhnologhichnogho universytetu. Serija : Ekonomichni nauky, 4, 296-304.

15. Kernel Holding S.A. and Subsidiaries Condensed Consolidated Interim Financial Statements for 6 months ended 31 December 2014. Retrieved from http://www.kernel.ua/media/uploads/library/14/ 10/KERNEL_FY_2014_Annual_Report.pdf.

16. Kernel Holding S.A. Annual Report and Accounts 30 June 2014. Retrieved from http://www.kernel.ua/ media/uploads/library/14/10/KERNEL_FY_2014_Annual_Report.pdf.

17. MHP S.A. Finansovi rezuljtaty za chetvertyj kvartal i dvanadcjatj misjaciv, jaki zakinchylysja 31 ghrudnja 2014 roku. Retrieved from www.mhp.com.ua/library/file/mhp-14fsu-final-ua.pdf.

18. MHP S.A. on the site London Stock Exchange. Retrieved from http://www.londonstockexchange.com/exchange/prices-and-markets/stocks/summary/company-summary/US55302T20 42USUSDIOBE. html.

19. Kernel Holding S.A. on the site Warsaw Stock Exchange. Retrieved from http://www.gpw.pl/karta_ spolki/LU0327357389/.

20. William H. Beaver. (1966). Financial ratios as predictors of failure, empirical research in accounting selected studies. Supplement to Journal of Accounting Research, 4, 71-111.

21. Posokhov, I. M. (2013). Vykorystannja systemy pokaznykiv U. Bivera dlja ocinky ryzyku bankrutstva korporacij. Visnyk SumDU. Serija "Ekonomika", 3, 65-72. 